\title{
How to Expand Repurchase Intention? The Intervening Impact of Attitude towards Mobile Shopping
}

\author{
Lutfi Nurcholis ${ }^{1 *}$; Raditya Ferdianto ${ }^{2}$ \\ ${ }^{1-2}$ Management Program, Faculty of Economic, Sultan Agung Islamic University \\ Jln. Kaligawe Raya, Jawa Tengah 50112, Indonesia \\ 1lutfinurcholis@unissula.ac.id; ${ }^{2 R a d i t y a f e r d i a n t o 0 @ g m a i l . c o m ~}$
}

Received: $15^{\text {th }}$ May 2020/ Revised: $27^{\text {th }}$ July 2020/ Accepted: $31^{\text {st }}$ August 2020

How to Cite: Nurcholis, L., \& Ferdianto, R. (2021). How to Expand Repurchase Intention? The Intervening Impact of Attitude towards Mobile Shopping. Binus Business Review, 12(1), 11-19. https://doi.org/10.21512/bbr.v12i1.6454

\begin{abstract}
The development of information technology has a significant impact on almost all activities in various fields, such as shopping. The perceived benefit and lower risk factors are significant factors for shopping on the Internet. However, the problem in shopping activities is the security risk factor in transactions and the lack of public knowledge and trust. There is a research gap in the relationship between perceived benefits and risks with purchase intention. Based on the phenomenon, the research aimed to investigate and test the attitude toward mobile shopping as a mediating variable at the relationship between perceived usefulness and perceived risk against repurchase intention. The research applied a quantitative approach to explain the relationship between research variables. The used sampling technique was purposive sampling with several criteria, with a total sample of 200 mobile shopping users in Central Java. Data collection was carried out using a questionnaire. The obtained data were processed using the SPSS 16. The results show that perceived usefulness and perceived risk affect attitude in mobile shopping and repurchase intention significantly. Then, attitude toward mobile shopping also influence repurchase intention. Last, it also finds that attitude toward mobile shopping can mediate the relationship between perceived usefulness and perceived risk against repurchase intention.
\end{abstract}

Keywords: repurchase intention, user attitude, mobile shopping, perceived usefulness, perceived risk

\section{INTRODUCTION}

The development of information technology has a significant impact on almost all activities in various fields. The transformative power of information technology has advanced companies and communities in accelerating the transition process to adjust with the support of the swift flow of obtained information. Thus, it forces people to have extensive knowledge to survive in this digital age (Racela \& Thoumrungroje, 2020). Technological developments are increasingly sophisticated, and the use of the Internet is increasingly popular in all circles of society without exception. Today's people prefer to do instant shopping, namely, shopping using the Internet and smartphones. Shopping activities using the Internet via a smartphone are now commonly referred to as mobile shopping.

The perceived benefit and lower risk factors are significant factors for shopping on the Internet. It shows that mobile shopping has received global acceptance because it provides various benefits for both businesses and consumers, such as offering payment options to consumers, streamlining the process of procuring goods or services, and making it easier for consumers to compare products with one another. However, the problem in shopping activities is the security risk factor in transactions and the lack of public knowledge and trust (Putro \& Haryanto, 2014). In the survey by Asosiasi Penyelenggara Jasa Internet Indonesia (Indonesian Internet Service Providers Association) in 2019, it revealed that $12,9 \%$ of the consumers preferred to shop directly because goods could be obtained immediately. Then, 7,5\% of Internet users did not want to shop online because they could not use the application. Moreover, 4,5\% worried that the goods would not arrive, and $2 \%$ felt the complicated transactions (Asosiasi Penyelenggara 
Jasa Internet Indonesia, 2019). Moreover, in a press release, Sutto (2018) stated that global online sales in 2017 reached US\$10,9 billion. This number increased by $41 \%$ from the US\$5,5 billion achieved in 2015 . It showed that online sales via the Internet became a very promising business infrastructure.

The success of M-Commerce is triggered by perceived usefulness and perceived risk by the users in mobile shopping. Then, it creates consumptive behavior that can foster repurchase intention. The risks in mobile shopping are usually problems in transactions, functions, physical products, social privacy, security, and time (Henry, Adiwijaya, \& Subagio, 2017). However, of the many things, the most often experienced risks are transaction risks, physical products, and privat security. The many felt risks by consumers can harm mobile shopping, making consumers learn from that. Previous research has found that perceived benefits and risks are factors that have a significant effect on purchase intention (Kahar, Wardi, \& Patrisia, 2019; Octaviani \& Gunawan, 2018; Setyorini \& Nugraha, 2016; Tho, Lai, \& Yan, 2017).

Perceived usefulness is defined as the extent to which consumers believe that the use of technology will improve their work performance (Setyorini \& Nugraha, 2016; Ghosh, 2020). The statement reinforces the Technology Acceptance Model (TAM) theory in the related research to online purchases. TAM is used to explain the perceived usefulness of a system mediated by attitude against repurchase intention. The perceived usefulness refers to the experience of consumers in mobile shopping. Users or consumers can get benefits or values if they can improve performance, productivity, and effectiveness in mobile shopping (Putro \& Haryanto, 2015). The perceived usefulness has a significant effect on purchasing attitudes on online shopping (Juniwati, 2014). It is also strengthened by descriptive statements from students who shop online that online shopping can offer more products, be flexibly done anywhere and at any time, meet needs faster, and reduce the less productive time (waiting in a queue, looking for parking areas, and getting stuck on a road) (Kadi, 2016).

Furthermore, another research reveals that the perceived usefulness has a significant effect on the attitude that influences the behavior in using Visual Hotel Program (VHP) software (Latifah \& Afifah, 2013). However, another research has different opinion that the perceived usefulness has no significant effect on the attitude toward mobile shopping that affects repurchase intention in mobile shopping (Cahyono \& Susanto, 2019). From the description, the first hypothesis can be developed as the following:

H1 : The perceived usefulness has a significant effect on attitude toward mobile shopping.

Consumers' perceived risks will affect the attitudes and interests of consumers in online shopping (Ghachem, Dobre, Etemad-Sajadi, \& Milovan-Ciuta, 2019; Al-Gasawneh \& Omer, 2020; Tham, Dastane,
Johari, \& Ismail, 2019). Perceived risk is caused by consumers' concerns about inappropriate or bad impacts experienced when shopping online. Based on previous research, the perceived risk has a negative and significant effect on attitude on online shopping (Juniwati, 2014). It means that if consumers feel a high risk of shopping online, the attitude of consumers to shop online will decrease. Mobile shopping consumers are concerned with the risk of shopping because sometimes the received product does not match the product images shown in the online shop, the product delivery period after the consumer makes a payment is long, and the quality of the product differs from the details described. In other words, shopping online has a high risk. Hence, the consumers' online shopping behavior should be studied based on attitude and perceived risk, resulting in more people to trade online. Then, it will have a significant influence on e-commerce development in Indonesia. In marketing literature, risk perception directly affects the purchase and purchase intent (Aminu, Olawore, \& Odesanya, 2019). When consumers perceive high risks, they are less likely to purchase or buy back online. The risk may be real, as long as it is perceived. It will influence the consumer's buying behavior (Tham et al., 2019). Previous research also states that perceived risk in online purchases has a significant effect on cognitive attitudes of purchasing, but not significantly on affective attitudes to purchasing (Kumar \& Mukherjee, 2013). It is also suggested that perceived risk negatively affects the attitude of universal online spending (Ariff, Sylvester, Zakuan, Ismail, \& Ali, 2014). From the description, the second hypothesis is:

H2 : Perceived risk has a significant effect on attitude toward mobile shopping.

In online business, individual consumers will be more likely to make several transactions or purchases when they assume that mobile shopping is useful (Cahyono \& Susanto, 2019). Consumers are more likely to do repurchase intention when they feel the benefits of mobile shopping. It proves that perceived usefulness positively impacts repurchase intention if consumers get the benefits or value of mobile shopping activities (Ventre \& Kolbe, 2020). The relationship of this variable is based on previous research, which states that perceived usefulness has a significant effect on repurchase intention (Santy \& Atika, 2020). It is the tendency of consumers who feel the benefits of mobile shopping to buy again in the future. The perceived usefulness is the main variable that significantly affects repurchase intention (Cahyono \& Susanto, 2019). However, another previous research reveals that perceived usefulness has no significant effect on repurchase intention (Oroh, 2015). From the description, the third hypothesis is as follows.

H3 : Perceived usefulness has a significant effect on repurchase intention. 
Perceived risk can also be defined as consumers' concerns about the results of their decisions (Arslan, Geçti, \& Zengin, 2013; Rejeki, 2018). The risks can be encountered in all purchasing processes carried out by consumers or once they face uncertainty, which can lead to unintended consequences (Tho et al., 2017). The perceived risk emphasizes the notion of an impact felt by someone when conducting online transactions (Mulyana, 2016). The high perceived risk will also cause high fear when shopping online (Guru, Nenavani, Patel, \& Bhatt, 2020; Bhukya \& Singh, 2015; Alnsour, Ismael, Nsoor, \& Feidi, 2019). Based on previous research, perceived risk negatively affects intention (Cheng, Tsai, Cheng, \& Chen, 2012; Tho et $a l ., 2017)$. It means that the more the received risks are by consumers, the less likely they will make a purchase (Ventre \& Kolbe, 2020; Rejeki, 2018). However, there is also a different opinion that perceived risk has no significant effect on repurchase intention (Indiani, Rahyuda, Kerti Yasa, \& Sukaatmadja, 2015). It shows a gap of research results in the effect of perceived risk on repurchase intention in mobile shopping. From the description, the fourth hypothesis is:

H4 : Perceived risk has a significant effect on repurchase intention.

Understanding the attitude toward mobile shopping will help to analyze consumers' behavior to increase their repurchase intentions. Therefore, this variable is one of the essential factors in predicting purchase decisions (Setyorini \& Nugraha, 2016). Consumers' attitudes toward an object are the result of repetitive learning. Attitudes associated with online purchases are formed from Internet interaction as a communication medium. The previous research confirms that consumer attitudes result from their previous experience in buying products online (Nurlaily, Noermijati, \& Hussein, 2017). If consumers' expectations in mobile shopping are met, most of them will intend to do repurchase in mobile shopping in the future (Núñez-Pomar, Prado-Gascó, Sanz, Hervás, $\&$ Moreno, 2016). Therefore, the researcher makes attitude a mediating variable between perceived usefulness and perceived risk against repurchase intention in mobile shopping. It has a significant effect on repurchase intention (Nurlaily et al., 2017). From the description, the last hypothesis is:

H5 : Attitude toward mobile shopping has a significant effect on repurchase intention.

From the mentioned statements, it can be concluded that the benefits and risks play an important role in one's intention to make a purchase. Based on it, the research uses the benefits and risk factors as research variables. However, some previous researchers show that benefits and risks do not significantly affect one's intention to buy (Henry et al., 2017; Juniwati, 2014; Oroh, 2015; Subagio, Mugiono, \& Hadiwidjojo, 2018). Based on the business phenomenon and the research gap, the research provides a role for attitude as a mediator. It is expected to become a solution based on the benefits and risks that consumers perceive for repurchase intentions on mobile shopping. It is in line with previous research, which states that attitude has a significant effect (Juniwati, 2014) and can play a mediating role in increasing consumer purchase intentions (Kadi, 2016). Hence, the research investigates and tests the role of attitude toward mobile shopping as a mediating variable in the relationship between perceived usefulness and perceived risk against repurchase intention. The research framework can be seen in Figure 1.

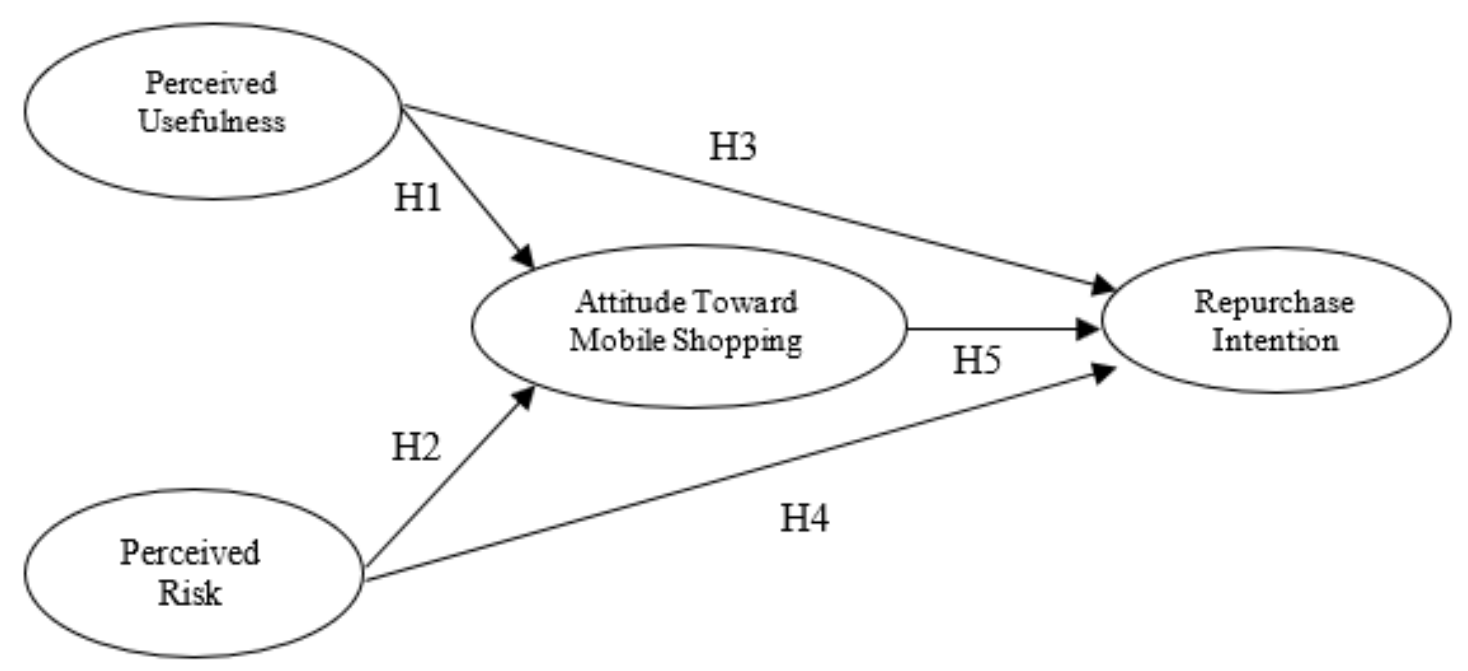

Figure 1 Research Framework 


\section{METHODS}

The research applies a quantitative approach to explain the relationship between the research variables. It aims to examine the relationship between the independent variables and the dependent variables that include perceived usefulness, perceived risk, attitude toward mobile shopping, and repurchase intention. The respondents are mobile shopping users in Central Java. The sampling technique is purposive sampling with several criteria. Data collection is carried out using a questionnaire. The users have made transactions at least once and are 17-35 years old. With these criteria, there are 200 respondents. The measurement scale uses a score of 1 to $10(1=$ strongly disagree and $10=$ strongly agree). Then, the data obtained are processed using SPSS 16. The definitions of the variables can be seen in Table 1 .

\section{RESULTS AND DISCUSSIONS}

The validity of data is tested using the Bivariate Pearson correlation. It is done by correlating each item's score with the total score. The items that correlate significantly with the total score indicate that these items can uncover what the researcher wants to reveal. If the significant value is $<0,05$, the items produce a significant value to the total score, or it is valid (Heale \& Twycross, 2015; Harpe, 2015). Table 2 shows that all indicators have Sig. of $<0,05$. It means that all items are valid. Similarly, Table 3 shows the variables have the Cronbach's alpha value of $>0,60$. Hence, the items in the research are reliable and feasible to use.

In Table 4, the independent variables have a Variance Inflation Factor (VIF) value of $<10$ and a tolerance value of $>0,10$. Hence, it can be concluded that there is no multicollinearity in the research model. The heteroscedasticity results use the results of the SPSS output through a scatterplot between the predicted value of the dependent variable (ZPRED) and the residual (SDRESID). The results of the data normality test show that the Kolmogorov Smirnov test in the first model has a sig. value of $0,055>0,05$. Meanwhile, the second model has a sig value of 0,147 $>0,05$. It implies that the data are normally distributed.

Table 5 shows the results of the hypothesis test. First, the perceived usefulness has a significant effect on attitude toward mobile shopping. It is proven by $\mathrm{p}$-value of $0,000<0,05$ with a t-value of 7,776 $>1,96$. So, $\mathrm{H} 1$ is accepted. It means that there is an effect of perceived usefulness on attitude toward mobile shopping. The more users feel the benefits of mobile shopping, the more positive their attitude towards mobile shopping will be. People think that shopping via smartphones has many benefits, such as making it easier for them to meet their needs faster to reduce unproductive time. Then, it will make people view online shopping as easy and useful. The result supports previous research of Juniwati (2014), stating that perceived usefulness has a significant effect on attitudes towards mobile shopping.

Table 1 Operational Variables

\begin{tabular}{|c|c|c|c|}
\hline No & Variable & Indicator & Sources \\
\hline 1 & $\begin{array}{l}\text { Perceived usefulness is consumers' } \\
\text { confidence in the perceived benefits of using } \\
\text { mobile shopping. }\end{array}$ & $\begin{array}{ll}\text { 1. } & \text { Make the job easier } \\
\text { 2. } & \text { Be useful } \\
\text { 3. } & \text { Enhance effectiveness } \\
\text { 4. Increase productivity } \\
\text { 5. Improve job performance }\end{array}$ & Cahyono and Susanto (2019) \\
\hline 2 & $\begin{array}{l}\text { Perceived risk is a concern about an } \\
\text { uncertain thing or a consequence that } \\
\text { follows the actions in mobile shopping. }\end{array}$ & $\begin{array}{ll}\text { 1. } & \text { Financial risk } \\
\text { 2. } & \text { Functional risk } \\
\text { 3. } & \text { Social risk } \\
\text { 4. } & \text { Psychological risk } \\
\text { 5. } & \text { Physical risk } \\
\text { 6. } & \text { Time risk } \\
\text { 7. } & \text { Perception risk }\end{array}$ & Mulyana (2016) \\
\hline 3 & $\begin{array}{l}\text { Attitude toward mobile shopping is a } \\
\text { cognitive and affective assessment of } \\
\text { consumers of an object in mobile shopping. }\end{array}$ & $\begin{array}{l}\text { 1. Consumers' confidence } \\
\text { 2. Consumers' opinions } \\
\text { 3. Consumers' feelings } \\
\text { 4. Consumers' actions } \\
\text { 5. Consumers' behaviors }\end{array}$ & Okpor and Najimu (2012) \\
\hline 4 & $\begin{array}{l}\text { Repurchase intention is the intention } \\
\text { of consumers to repurchase as an act of } \\
\text { experience. }\end{array}$ & $\begin{array}{l}\text { 1. Tendency to recommend } \\
\text { 2. Preference tendencies } \\
\text { 3. Tendency to find information } \\
\text { 4. Tendency to buy again }\end{array}$ & Tho et al. (2017) \\
\hline
\end{tabular}


Second, perceived risk has a significant effect on the attitude toward mobile shopping. $\mathrm{H} 2$ is accepted. The result shows p-value of $0,000<0,05$ with t-value of $10,166>1,96$. It implies there is an effect of perceived risk on attitude toward mobile shopping. The smaller the risk is perceived by mobile shopping users, the higher their attitude will be. Unlike shopping in person, online shopping is associated with a risk that consumers do not always get the product they order after making a transaction. Therefore, if this risk perception is high, consumers' attitudes towards online shopping will decline. The result is also supported by previous research by Kumar and Mukherjee (2013), suggesting that risk perceptions have a significant positive effect on attitudes towards mobile shopping.

Third, perceived usefulness has a significant effect on repurchase intention. Hence, $\mathrm{H} 3$ is accepted, The result has a $p$-value of $0,002<0,05$ with a t-value of $3,107>1,96$. It shows that there is an effect of perceived usefulness on repurchase intention. The increased perceived benefits of shopping through mobile shopping will increase consumers' repurchase intentions. There is also an argument that there is a strong direct relationship between usability and intention to use (Davis, 1989). It explains why consumers intend to use technology because of its benefits. The more people who think that technology is useful, the more they intend to use it. In online shopping, if people find online shopping is useful, offers many product alternatives, meets their needs more quickly, and reduces the time for unproductive activities, people will use online shopping more often. It can be defined that the relationship between perceived usefulness and online shopping intentions is positive. The results of the research support previous research by Santy and Atika (2020). They stated that perceived usefullness had a significant effect on repurchase intentions.

Fourth, perceived risk has a significant effect on repurchase intention. $\mathrm{H} 4$ is accepted. It shows a p-value of $0,000<0,05$ with a t-value of $4,265>$ 1,96 . There is an effect of perceived risk on repurchase intention. The smaller the perceived risk in shopping is, the higher the consumers' repurchase intentions will be. According to Mulyana (2016), perceived risk emphasizes the assumption about the impact a person will feel when making online transactions. The high risk will also create a high level of fear, especially when transacting online. Based on these assumptions, it can be concluded that risk perceptions can influence consumer repurchase interest in online shopping. The result is in line with the previous research (Tho et al., 2017; Henry et al., 2017).

Table 2 The Result of Validity Test

\begin{tabular}{|c|c|c|c|c|c|}
\hline No & Variable & Indicator & R Calculation & Sig. & Information \\
\hline \multirow[t]{5}{*}{1} & \multirow{5}{*}{$\begin{array}{l}\text { Perceived } \\
\text { Usefulness }\end{array}$} & Make the job easier & 0,835 & 0,000 & Valid \\
\hline & & Be usefull & 0,832 & 0,000 & Valid \\
\hline & & Enchance effectiveness & 0,838 & 0,000 & Valid \\
\hline & & Increase productivity & 0,851 & 0,000 & Valid \\
\hline & & Improve job performance & 0,813 & 0,000 & Valid \\
\hline \multirow[t]{7}{*}{2} & \multirow[t]{7}{*}{ Perceived Risk } & Financial risk & 0,799 & 0,000 & Valid \\
\hline & & Functional risk & 0,909 & 0,000 & Valid \\
\hline & & Social risk & 0,900 & 0,000 & Valid \\
\hline & & Phychological risk & 0,909 & 0,000 & Valid \\
\hline & & Physical risk & 0,885 & 0,000 & Valid \\
\hline & & Time risk & 0,814 & 0,000 & Valid \\
\hline & & Perception risk & 0,861 & 0,000 & Valid \\
\hline \multirow[t]{5}{*}{3} & \multirow{5}{*}{$\begin{array}{l}\text { Attitude } \\
\text { Toward Mobile } \\
\text { Shopping }\end{array}$} & Consumers' confidence & 0,835 & 0,000 & Valid \\
\hline & & Consumers' opinions & 0,867 & 0,000 & Valid \\
\hline & & Consumers' feelings & 0,855 & 0,000 & Valid \\
\hline & & Consumers' actions & 0,852 & 0,000 & Valid \\
\hline & & Consumers' behaviors & 0,828 & 0,000 & Valid \\
\hline \multirow[t]{4}{*}{4} & \multirow{4}{*}{$\begin{array}{l}\text { Repurchase } \\
\text { Intention }\end{array}$} & Tendency to recommend & 0,864 & 0,000 & Valid \\
\hline & & Preference tendencies & 0,901 & 0,000 & Valid \\
\hline & & Tendency to find information & 0,910 & 0,000 & Valid \\
\hline & & Tendency to buy again & 0,895 & 0,000 & Valid \\
\hline
\end{tabular}


Fifth, attitude toward mobile shopping has a significant effect on repurchase intention. H5 is accepted. The results show a p-value of $0,000<0,05$ with a t-value of 4,011 > 1,96. There is an effect of attitude toward mobile shopping on repurchase intention. The greater the attitude towards mobile shopping is, the higher the consumers' repurchase intentions will be. A positive attitude increases the repurchase intention in mobile shopping. It is because attitude is a learned tendency to behave pleasantly or unpleasantly towards a particular object, such as consumers who like and dislike a product. The result is strengthened by Nurlaily et al. (2017). They emphasized that consumers' attitudes were the result of their previous experiences in buying products online. Based on this description, it can be concluded that the attitude towards mobile shopping has a significant effect on repurchase intention.

Table 6 shows the estimated parameters of indirect path effects. First, the perceived usefulness on repurchase intention through attitude toward mobile shopping using Sobel test results in 3,559 and $\mathrm{p}$-value of $0,000<0,05$. Hence, attitudes towards mobile shopping can mediate the relationship between perceived usefulness and repurchase intention. The result proves that attitudes can affect the benefits felt by consumers, which will increase the repurchase intention. It is in line with previous research which states that attitude has a significant effect and can play a mediating role in increasing consumer purchase intentions (Kadi, 2016).

Table 3 The Result of Reliability Test

\begin{tabular}{clcc}
\hline No & Variable & Cronbach's Alpha & Information \\
\hline 1 & Perceived Usefulness & 0,828 & Reliable \\
2 & Perceived Risk & 0,825 & Reliable \\
3 & Attitude Toward Mobile Shopping & 0,745 & Reliable \\
4 & Repurchase Intention & 0,807 & Reliable \\
\hline
\end{tabular}

Table 4 The Result of Classical Assumption Test

\begin{tabular}{cccccc}
\hline Model & Dependent variable & Independent variable & Tolerance & VIF & $\begin{array}{c}\text { Kolmogorov } \\
\text { Smirnov test }\end{array}$ \\
\hline \multirow{2}{*}{ Regression 1 } & $\begin{array}{c}\text { Attitude Toward Mobile } \\
\text { Shopping }\end{array}$ & Perceived Usefulness & 0,750 & 1,334 & \\
& & Perceived Risk & 0,750 & 1,334 & 0,055 \\
\hline \multirow{2}{*}{ Regression 2 } & \multirow{2}{*}{ Repurchase Intention } & Perceived Usefulness & 0,574 & 1,743 \\
& & Perceived Risk & 0,492 & 2,034 & 0,147 \\
& & Attitude Toward Mobile Shopping & 0,378 & 2,645 & \\
\hline
\end{tabular}

Table 5 Hypothesis Testing Results

\begin{tabular}{clcccccc}
\hline Model & Hypotheses & Standardized $\boldsymbol{\beta}$ & Unstandardized $\boldsymbol{\beta}$ & Standard Error & T-Value & P-Value & Information \\
\hline \multirow{2}{*}{1} & H1: PU $\rightarrow$ AT & 0,393 & 0,515 & 0,066 & 7,776 & 0,000 & Accepted \\
& H2: PR $\rightarrow$ AT & 0,514 & 0,387 & 0,038 & 10,166 & 0,000 & Accepted \\
\multirow{2}{*}{2} & H3: PU $\rightarrow$ RI & 0,203 & 0,187 & 0,060 & 3,107 & 0,002 & Accepted \\
& H4: PR $\rightarrow$ RI & 0,301 & 0,160 & 0,037 & 4,265 & 0,000 & Accepted \\
& H5: AT $\rightarrow$ RI & 0,323 & 0,228 & 0,057 & 4,011 & 0,000 & Accepted \\
\hline
\end{tabular}

Note: Perceived Usefulness (PU), Perceived Risk (PR), Attitude Toward Mobile Shopping (AT), and Repurchase Intention (RI)

Table 6 The Estimated Parameters of Indirect Path Effects Using Sobel Test

\begin{tabular}{clcc}
\hline No & Lane & Sobel Test & P-Value \\
\hline 1 & $\mathrm{PU} \rightarrow \mathrm{AT} \rightarrow \mathrm{RI}$ & 3,559 & 0,000 \\
2 & $\mathrm{PR} \rightarrow \mathrm{AT} \rightarrow \mathrm{RI}$ & 3,723 & 0,000 \\
\hline
\end{tabular}

Note: Perceived Usefulness (PU), Perceived Risk (PR), Attitude Toward Mobile Shopping (AT), and Repurchase Intention (RI). 
Second, there is an effect of perceived risk on repurchase intention through attitude toward mobile shopping obtained from the Sobel test value of 3,723 and $p$-value of $0,000<0,05$. The result indicates that attitude toward mobile shopping is accepted as a mediating variable between perceived risk and repurchase intention. It proves that attitudes can affect the risk felt by consumers in shopping and will increase repurchase intentions. The attitude of experienced risk or loss by consumers will be bad in mobile shopping. The experience will form a bad perception for consumers of mobile shopping. The result is in line with previous research which suggests that attitude has a significant effect and can mediate a role in increasing consumer purchase intentions (Juniwati, 2014).

Based on the research findings, it provides managerial implications in e-commerce to continue to increase consumers' purchase intentions. First, the stakeholders, especially the management team and IT team, must pay more attention to the risk aspect. This aspect is proven to influence consumers' intentions and attitudes. Hence, the management, in this case the marketing department, must communicate and promote it well and on target so it can be understood and can convince consumers that $\mathrm{m}$-commerce is a safe shopping place. On the other hand, the IT team in this context must also manage risk by developing a mobile platform that can minimize unwanted things to increase consumers' intentions and provide a comfortable and useful shopping experience.

Second, to increase benefits when transacting and the intention to make repeat purchases or transactions on the e-commerce, feature updates and ease of transactions must focus on simplifying the customers' journey where they can choose products according to their preferences and budget. Third, discounts, cashback, insurance, delivery services, and payment channels can be presented systematically. Consumers must easily understand it. Also, to facilitate purchasing activities in e-commerce, call center services via telephone and online chat must be available to make it easier for consumers to get the needed information and solutions.

\section{CONCLUSIONS}

The findings indicate a significant influence on perceived usefulness and perceived risk on attitude toward mobile shopping and a significant effect on perceived usefulness and perceived risk on repurchase intention. The benefits and risks of shopping via the Internet are generally hypothesized to be antecedents of purchase attitudes and intentions that act as major predictors of new technology acceptance. The intention to transact via mobile devices is the dependent variable in the research. From several findings that have been described, it shows that the benefits and risks are several essential factors for interpersonal and commercial relationships. Further results indicate that attitudes can mediate perceived usefulness and perceived risk for repurchase intention. It suggests that attitudes can be mediation or solution in overcoming gaps that have been found in previous research in influencing consumer purchase intentions.

The research certainly has several limitations. The data analysis unit only focuses on users or customers who have made transactions through mobile shopping platforms and have an age range of 17-34 years. Furthermore, the research is only conducted in Central Java and does not focus on a single mobile platform. Thus, it is expected that further research can use the context of websites, social media platforms, or tablet apps. The research can also be carried out in other big cities and focus on one mobile platform.

\section{REFERENCES}

Al-Gasawneh, J., \& Omer, K. (2020). Moderating role of content marketing on the relationship between perceived risk and the intention to online shopping. Journal of Theoretical and Applied Information Technology, 99(02),1992-8645.

Alnsour, M., Ismael, N., Nsoor, Z., \& Feidi, M. (2019). The perceived risks affecting online shopping adoption in Jordan. International Journal of Online Marketing (IJOM), 9(2), 1-12. https://doi.org/10.4018/ ijom.2019040101

Aminu, S. A., Olawore, O. P., \& Odesanya, A. E. (2019). Perceived risk barriers to internet shopping. KIU Journal of Social Sciences, 5(2), 69-81.

Asosiasi Penyelenggara Jasa Internet Indonesia. (2019). Laporan Survei Internet APJII 2019-2020 [Q2]. Retrieved from https://apjii.or.id/survei

Ariff, M. S. M., Sylvester, M., Zakuan, N., Ismail, K., \& Ali, K. M. (2014). Consumer perceived risk, attitude and online shopping behaviour; empirical evidence from Malaysia. IOP Conference Series: Materials Science and Engineering, 58, 1-10. https://doi. org/10.1088/1757-899X/58/1/012007

Arslan, Y., Geçti, F., \& Zengin, H. (2013). Examining perceived risk and its influence on attitudes: A study on private label consumers in Turkey. Asian Social Science, 9(4), 158-166. https://doi.org/10.5539/ass. v9n4p158

Bhukya, R., \& Singh, S. (2015). The effect of perceived risk dimensions on purchase intention: An empirical evidence from Indian private labels market. American Journal of Business, 30(4), 218-230. https://doi.org/10.1108/ajb-10-2014-0055

Cahyono, T. A., \& Susanto, T. D. (2019). Acceptance factors and user design of mobile e-government website (Study case e-government website in Indonesia). Procedia Computer Science, 161, 90-98. https://doi. org/10.1016/j.procs.2019.11.103

Cheng, S., Tsai, M., Cheng, N., \& Chen, K. (2012). Predicting intention to purchase on group buying website in Taiwan: Virtual community, critical mass and risk. Online Information Review, 36(5), 698712. https://doi.org/10.1108/14684521211275984

Davis, F. D. (1989). Perceived usefulness, perceived 
ease of use, and user acceptance of information technology. MIS Quarterly, 13(3), 319-340. https:// doi.org/10.2307/249008

Ghachem, L., Dobre, C., Etemad-Sajadi, R., \& MilovanCiuta, A. (2019). The impact of cultural dimensions on the perceived risk of online shopping. Studia UBB Negotia, 64(3), 7-28. https://doi.org/10.24193/ subbnegotia.2019.3.01

Ghosh, S. (2020). Determinants of consumers' perceived experience value in relation to online organic food purchase. Universal Journal of Management, 8(3), 74-81. https://doi.org/10.13189/ujm.2020.080304

Guru, S., Nenavani, J., Patel, V., \& Bhatt, N. (2020). Ranking of perceived risks in online shopping. Decision, 47, 137-152. https://doi.org/10.1007/ s40622-020-00241-x

Harpe, S. E. (2015). How to analyze Likert and other rating scale data. Currents in Pharmacy Teaching and Learning, 7(6), 836-850. https://doi.org/10.1016/j. cptl.2015.08.001

Heale, R., \& Twycross, A. (2015). Validity and reliability in quantitative studies. Evidence-Based Nursing, 18(3), 66-67. https://doi.org/10.1136/eb-2015-102129

Henry, K., Adiwijaya, M., \& Subagio, H. (2017). Pengaruh perceived risk terhadap purchase intention dengan mediasi perceived value dan customer attitude pada pelanggan online shopping melalui media sosial Facebook di Surabaya. Petra Business and Management Review, 3(2), 62-83.

Indiani, N. L. P., Rahyuda, I. K., Kerti Yasa, N. N., \& Sukaatmadja, I. (2015). Perceived risk and trust as major determinants of actual purchase, transcending the influence of intention. ASEAN Marketing Journal, 7(1), 1-13. https://doi.org/10.21002/amj. v7i1.4601

Juniwati, J. (2014). Influence of perceived usefulness, ease of use, risk on attitude and intention to shop online. European Journal of Business and Management, 6(27), 218-229.

Kadi, D. C. A. (2016). Peran sikap sebagai pemediasi terhadap pengaruh persepsi harga dan persepsi kualitas pada niat beli (Survei niat beli konsumen pada kerajinan kulit di Kabupaten Magetan). Al Tijarah, 2(2), 211-229. https://doi.org/10.21111/ tijarah.v2i2.743

Kahar, A., Wardi, Y., \& Patrisia, D. (2019). The influence of perceived of usefulness, perceived ease of use, and perceived security on repurchase intention at Tokopedia.com. In Proceedings of the $2^{\text {nd }}$ Padang International Conference on Education, Economics, Business and Accounting (PICEEBA-2 2018). https://doi.org/10.2991/piceeba2-18.2019.20

Kumar, A., \& Mukherjee, A. (2013). Shop while you talk: Determinants of purchase intentions through a mobile device. International Journal of Mobile Marketing, 8(1), 23-37.

Latifah, L., \& Afifah, A. N. (2013). Pengaruh variabel perceived usefulness, perceived ease of use, perceived enjoyment dan attitude terhadap pemanfaatan visual hotel program pada hotel-hotel di Yogyakarta. JRAK: Jurnal Riset Akuntansi \&
Komputerisasi Akuntansi, 4(01), 33-47.

Mulyana, Y. F. (2016). Pengaruh kepercayaan, persepsi risiko, dan keamanan terhadap minat beli konsumen pada toko online (Studi pada toko online OLX.co.id) (Skripsi). Unversitas Negeri Yogyakarta.

Okpor, I., \& Najimu, H. (2012). Public-private partnership for skill acquisition and vocational technical education development in Nigeria. Mediterranean Journal of Social Sciences, 3(4), 91-94.

Núñez-Pomar, J., Prado-Gascó, V., Sanz, V. A., Hervás, J. C., \& Moreno, F. C. (2016). Does size matter? Entrepreneurial orientation and performance in Spanish sports firms. Journal of Business Research, 69(11), 5336-5341. https://doi.org/10.1016/j. jbusres.2016.04.134

Nurlaily, I., Noermijati, \& Hussein, A. S. (2017). Influence of life style and attitude toward trust and repeat purchase intentions on social media users (Study on Instagram users in Malang). Wacana, Jurnal Sosial dan Humaniora, 20(2), 68-78.

Octaviani, E. S., \& Gunawan, H. (2018). Perceived risk on consumer online shopping behaviour. Journal of Applied Accounting and Taxation, 3(2), 203-209. https://doi.org/10.30871/jaat.v3i2.876

Oroh, C. R. (2015). The influence of perceived ease of use, perceived usefulness and trust on repurchase intention of Lion Air e-ticket. Jurnal Berkala Ilmiah Efisiensi, 15(5), 367-376.

Putro, H., \& Haryanto, B. (2015). Factors affecting purchase intention of online shopping in Zalora Indonesia. British Journal of Economics, Management \& Trade, 9(1), 1-12. https://doi.org/10.9734/ bjemt $/ 2015 / 18704$

Racela, O. C., \& Thoumrungroje, A. (2020). Enhancing export performance through proactive export market development capabilities and ICT utilization. Journal of Global Marketing, 33(1), 46-63. https:// doi.org/10.1080/08911762.2018.1549302

Rejeki, D. S. (2018). Anteseden perceived risk pada purchase intention. Jurnal Manajemen dan Pemasaran Jasa, 11(1), 145-160. https://doi.org/10.25105/jmpj. v11i1.2570

Santy, R. D., \& Atika, S. D. (2020). Purchasing decisions in terms of perceived quality and product knowledge. In International Conference on Business, Economic, Social Science, and Humanities-Economics, Business and Management Track (ICOBESTEBM 2019) (pp. 94-99). Atlantis Press. https://doi. org/10.2991/aebmr.k.200108.023.

Setyorini, R., \& Nugraha, R. P. (2016). The effect of trust towards online repurchase intention with perceived usefulness as an intervening variable: A study on KASKUS marketplace customers. The Asian Journal of Technology Management, 9(1), 1-7.

Subagio, D. P. W., Mugiono, \& Hadiwidjojo, D. (2018). Pengaruh perceived ease of use terhadap repurchase usefulness dan trust sebagai variabel mediasi. Jurnal Manajemen dan Kewirausahaan, 6(1), 35-44. https://doi.org/10.26905/jmdk.v6i1.2067

Sutto, M. (2018). The state of ecommerce in Southeast Asia in 2017. Retrieved from https://medium.com/swlh/ 
the-state-of-ecommerce-in-southeast-asia-in-20175a779f962623

Tham, K. W., Dastane, O., Johari, Z., \& Ismail, N. B. (2019). Perceived risk factors affecting consumers' online shopping behaviour. The Journal of Asian Finance, Economics, and Business, 6(4), 246-260. https://doi. org/10.13106/jafeb.2019.vol6.no4.249

Tho, N. X., Lai, M. T., \& Yan, H. (2017). The effect of perceived risk on repurchase intention and word of - mouth in the mobile telecommunication market: A case study from Vietnam. International Business Research, 10(3), 8-19. https://doi.org/10.5539/ibr. v10n3p8

Ventre, I., \& Kolbe, D. (2020). The impact of perceived usefulness of online reviews, trust and perceived risk on online purchase intention in emerging markets: A Mexican perspective. Journal of International Consumer Marketing, 32(4), 287-299. https://doi.or $\mathrm{g} / 10.1080 / 08961530.2020 .1712293$ 